\title{
Monitoring of the main zoonoses in the North- Western region of the Caucasus
}

\author{
Petr Miroshnichenko ${ }^{1,{ }^{*}}$, Nikolai Kruzhnov ${ }^{1}$, Natalia Basova ${ }^{1}$, Michael Staroselov ${ }^{1}$, and \\ Alexander Skorikov ${ }^{1}$ \\ ${ }^{1}$ Krasnodar Research Centre for Animal Husbandry and Veterinary Medicine, 4, Pervomaiskaya str., \\ Krasnodar, 350055, Russia
}

\begin{abstract}
In the process of work an assessment of the characteristics of the epizootic manifestation of quarantine diseases of animals and poultry as well as the risks of their occurrence and spread were made. On the territory of the Russian Federation are registered more than 30 nosological forms of infections, infestations and foodborne toxicological infections. According to the research, the epizootic situation in Krasnodar region regarding quarantine infections remains stable, despite the registration of 755 adverse areas for quarantine infections over a 10 year observation period. Since 2013, the number of adverse areas has decreased from 119 to 32. A similar trend is observed in the decrease in the linear trend of the focal incidence from 102.3 to 10.1 . The highest focal index for the study period was found in cases of avian influenza - 112.9, African swine fever 105.3 and bovine leucosis -55.8. An increased risk of the occurance of the diseases of this group on the territory of Krasnodar region exists in marchapril-may, june and august.
\end{abstract}

\section{Introduction}

The North-Western region of the Caucasus is the border territory of the Russian Federation, therefore, monitoring of infectious, zoonotic diseases of animals and poultry as well as forecasting and sending proposals to the executive authorities in the field of veterinary medicine to adjust regional programs for the prevention of these diseases depending on the epizootic situation in the region are timely and relevant [1-3].

Microbiological monitoring serves as an information base for modern epizootology and epidemiology and allows to influence the effectiveness of infection surveillance activities. The increasing globalization of food trade, the movement of animals and livestock products from one region to another, between states, and sometimes between continents, increases the risk of the spread of animals and poultry infectious diseases, including deseases dangerous for humans [3-7].

Therefore, there is a need for intensification and improvement of monitoring and state surveillance of the epizootic and epidemic situation both at the state level as a whole and in specific regions of the Russian Federation [8].

\footnotetext{
*Corresponding author: mpetrvas@mail.ru
} 
Thereby, the solution of the zooanthroponosis problem is the introduction of elements of epizootological and epidemiological monitoring and surveillance of changes in the nosological profile of diseases that are common for humans and animals [9-11].

Modern methods of epizootological monitoring make it possible to restrain animal infectious pathologies and to improve veterinary control over the safety of livestock products $[12,13]$.

In Russia over the past decades the methodology, as an integral component of epidemiology and epizootology, is rapidly modernizing, therefore, epidemiological and epizootological monitoring and surveillance were included in the system of anti-epidemic and anti-epizootic measures [14, 15].

The aim of the research was to conduct the epizootological monitoring of the most common infectious diseases of animals in the North-West region of the Caucasus.

The scientific novelty of the research lies in the fact that for the first time new knowledge on the dynamics of the epizootic manifestations of especially dangerous zoonoses in the North-West region of the Caucasus has been gained that made it possible to forecast the occurrence, spread, prevention and minimization of the risks of eliminating these infections, and reduce the incidence and mortality, increase the safety of animals and poultry and increase the effectiveness of the conducted diagnostic studies.

\section{Materials and Methods}

The tasks were performed using methods of epizootological analysis and visits to livestock farms of Krasnodar region, analysis of the results of microbiological, serological studies and data of veterinary reporting of the State Administration of Veterinary Medicine of Krasnodar region, veterinary laboratories and reports of the Krasnodar Veterinary Research Institute. Research and analysis was carried out on the basis of the departments of: especially dangerous infections and molecular diagnostics of SBI "Kropotkinsk regional veterinary laboratory", FSBI "Krasnodar interregional veterinary laboratory" and department of antiepizootic measures SPI "Regional station for fiting with animal diseases".

During the research, Russian methodologies were used, described in: "Recommendations on the methodology of epizootic analysis", "Quantitative epizootology: the basics of applied epidemiology and biostatistics" and "Epizootological research method".

\section{Results}

Since the beginning of 2019, 22 unfavorable points have been registered on the territory of the Krasnodar territory for infectious diseases of animals, including: brucellosis of large and small cattle-16, rabies of wild carnivores, bovine leukemia, tuberculosis and Newcasle disease-1, avian ornithosis and leptospirosis-2, a total of 6(Table 1).

In 2019, in the region with the aim of preventing quarantine and especially dangerous infections, the following number of animals were examined: for brucellosis - 473.6 thousand heads of cattle (175 of them reacted positively), 138.6 thousand heads of small cattle (41 animals reacted positively); 11.4 thousand heads of horses; for leptospirosis 38.0 thousand heads of cattle and 11.2 thousand heads of small cattle; for leukemia - 419.0 thousand heads of cattle; for tuberculosis - allergic 478.2 thousand heads of cattle (1.8 thousand heads reacted positively); for glanders - 11.3 thousand heads of horses; for rabies - 0.1 thousand samples; for anthrax - 0.4 thousand samples.

Against anthrax were vaccinated 493.8 thousand heads of cattle; against foot-and-mouth 
disease - 654.5 thousand animals, against infectious cattle nodular dermatitis - 516.4 thousand animals, against rabies - 57.5 thousand animals, 192.6 thousand dogs, 239.8 thousand cats, against avian influenza and Newcastle disease - 4090.6 thousand poultry and 239.8 thousand doses of the vaccine were used to immunize wild animals against rabies.

Five infected areas were discovered for African swine fever and adverse catarrh fever of cattle (bluetongue).

During 2018 twenty three adverse areas were recorded for quarantine and especially dangerous animal diseases, including cattle leukemia - 3, for animal brucellosis - 14 , for African swine fever - 2 focuses of disease and 3 infected objects, and for rabies of carnivore -4 .

Table 1. The number of adverse areas of quarantine and infectious diseases in Krasnodar region in 2009-2019.

\begin{tabular}{|c|c|c|c|c|c|c|c|c|c|c|c|c|c|}
\hline Disease & હ્ન & 옥 & $\overline{\bar{\pi}}$ & 고ํ & ֻี & 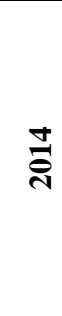 & 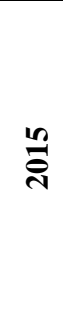 & 룰 & ำ & $\stackrel{\infty}{\frac{\pi}{1}}$ & ते & $\begin{array}{l}\stackrel{\sigma \pi}{0} \\
\stackrel{\Xi}{\Xi}\end{array}$ & 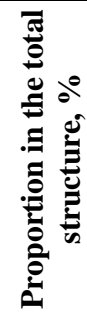 \\
\hline Brucellosis & 12 & 20 & 20 & 18 & 14 & 29 & 22 & 24 & 25 & 24 & 24 & 232 & 30.7 \\
\hline Bovine leukosis & 8 & 2 & - & - & 83 & 55 & 17 & 5 & 2 & 4 & 1 & 177 & 23.4 \\
\hline Rabies & 30 & 35 & 21 & 13 & 16 & 13 & 10 & 4 & 2 & 9 & 1 & 154 & 20.4 \\
\hline $\begin{array}{l}\text { African swine } \\
\text { fever }\end{array}$ & 5 & 19 & 17 & 27 & 1 & - & 1 & 4 & 2 & 2 & - & 78 & 10.3 \\
\hline Ornithosis & 8 & 7 & 9 & 6 & 1 & 2 & 5 & 6 & 3 & 1 & 2 & 50 & 6.6 \\
\hline Leptospirosis & - & 3 & 2 & & 2 & 2 & 2 & 1 & 2 & - & 2 & 16 & 2.1 \\
\hline Tuberculosis & - & 1 & 1 & 3 & 1 & 1 & 1 & $\begin{array}{llll}- & & & \\
\end{array}$ & 2 & $\begin{array}{llll}- & \\
\end{array}$ & 1 & 11 & 1.5 \\
\hline $\begin{array}{l}\text { Classical swine } \\
\text { fever }\end{array}$ & 1 & - & 6 & - & - & - & - & - & - & - & - & 7 & 0.9 \\
\hline $\begin{array}{l}\text { Nodular } \\
\text { dermatitis }\end{array}$ & - & - & - & - & - & - & - & 5 & - & - & - & 5 & 0.7 \\
\hline Avian influenza & - & - & - & 1 & - & - & - & 2 & 2 & - & - & 5 & 0.7 \\
\hline $\begin{array}{l}\text { Malignant } \\
\text { edema }\end{array}$ & 4 & - & - & - & - & - & - & - & - & - & - & 4 & 0.5 \\
\hline $\begin{array}{l}\text { Swine } \\
\text { pasteurellosis }\end{array}$ & 3 & - & - & 1 & - & - & - & - & - & - & - & 4 & 0.5 \\
\hline Dourine & 1 & $\begin{array}{llll}- & \\
\end{array}$ & - & 1 & - & 1 & - & - & $\begin{array}{llll}- & \\
\end{array}$ & - & - & 3 & 0.4 \\
\hline Anthrax & - & 1 & - & 1 & - & - & - & - & - & - & - & 2 & 0.3 \\
\hline Blackleg & 2 & - & - & - & - & - & - & - & - & - & - & 2 & 0.3 \\
\hline $\begin{array}{l}\text { Newcasle } \\
\text { disease }\end{array}$ & - & - & - & - & - & - & - & - & - & - & 1 & 1 & 0.1 \\
\hline $\begin{array}{l}\text { Foot-and-mouth } \\
\text { disease }\end{array}$ & - & - & - & - & 1 & - & - & - & - & - & - & 1 & 0.1 \\
\hline Bluetongue & 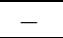 & - & $\begin{array}{ll}- & \\
\end{array}$ & $\begin{array}{llll}- & \\
\end{array}$ & $\begin{array}{llll}- & & & \\
\end{array}$ & 1 & - & $\begin{array}{llll}- & & & \\
\end{array}$ & $\begin{array}{llll}- & \\
\end{array}$ & $\begin{array}{llll}- & \\
\end{array}$ & $\begin{array}{llll}- & & & \\
\end{array}$ & 1 & 0.1 \\
\hline Braxy of sheep & 1 & - & - & $\begin{array}{ll}- \\
-\end{array}$ & $\begin{array}{ll}- \\
-\end{array}$ & - & - & $\begin{array}{ll}- \\
-\end{array}$ & $\begin{array}{ll}- \\
-\end{array}$ & - & $\begin{array}{ll}- \\
-\end{array}$ & 1 & 0.1 \\
\hline Edema disease & 1 & - & - & - & - & - & - & - & - & - & - & 1 & 0.1 \\
\hline In total & 76 & 88 & 76 & 71 & 119 & 104 & 58 & 51 & 40 & 40 & 32 & 755 & 100.0 \\
\hline
\end{tabular}


In order to carry out monitoring for 2019, in the region were examined 7.1 thousand blood serum samples and 0.8 thousand diagnostic samples from poultry and wild birds for the intensity of immunity to avian influenza virus; 47.3 thousand samples from pigs, 518 samples from 281 wild boars and 538 samples of ticks were examined for African swine fever.

Over the past 10 years of observation, from 2009 to 2019, 755 adverse areas of quarantine animal diseases were registered in Krasnodar region (Table 1)

The diseases are represented by 20 nosological units, such as: anthrax, brucellosis, rabies, tuberculosis, leptospirosis, ornithosis, avian influenza, foot-and-mouth disease, chlamydia, bluetongue, classical and African swine fever, lumpy skin desease of cattle, malignant edema, swine pasteurellosis, dourine, emphysematous carbuncle, Newcastle disease, braxy of sheep, edema disease.

In the nosological profile of quarantine infections a dominant position is occupied by: brucellosis, bovine leukosis, rabies, African swine fever, ornithosis up to $91.5 \%$ of the total number of adverse areas.

Among them brucellosis accounted for the largest number of adverse areas $-30.7 \%$, bovine leukosis - $23.4 \%$, African swine fever - 20.4\%; less than $1 \%$ accounted for classical swine fever, lumpy skin desease, malignant edema, swine pasteurellosis, dourine horse disease, anthrax and blackleg; up to $0.1 \%$ accounted for Newcastle disease, foot-and-mouth disease and bluetongue of cattle, braxy of sheep and edema disease.

In total, more than 40.4 thousand animals and poultry got sick with quarantine infections in 755 adverse areas (Table 2).

Table 2. Epizootic situation on quarantine and infectious diseases in Krasnodar region according to the data of 2009-2019.

\begin{tabular}{|c|c|c|c|c|c|c|c|c|c|c|c|c|}
\hline \multirow[b]{2}{*}{ Indicator } & \multicolumn{11}{|c|}{ Year } & \multirow[b]{2}{*}{$\underset{\text { total }}{\text { In }}$} \\
\hline & હิ & $\stackrel{ }{\text { ㄱ. }}$ & ন্ন & 곡 & 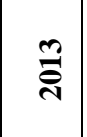 & ষ্ণ & $\frac{\pi}{8}$ & ำ & 곡 & 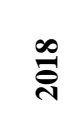 & 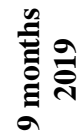 & \\
\hline $\begin{array}{l}\text { Number of } \\
\text { adverse areas }\end{array}$ & 76 & 88 & 76 & 71 & 119 & 104 & 58 & 51 & 40 & 40 & 32 & 755 \\
\hline $\begin{array}{l}\text { Number of } \\
\text { desease cases }\end{array}$ & 8470 & 4724 & 4269 & 11586 & 1965 & 798 & 820 & 5215 & 1291 & 926 & 323 & 40387 \\
\hline Focal incidence & 111.4 & 53.7 & 56.2 & 163.2 & 16.5 & 7.7 & 14.1 & 102.3 & 32.3 & 23.2 & 10.1 & 53.5 \\
\hline
\end{tabular}

The maximum number of adverse areas was determined in 2013 - 119 areas, and the minimum in 2019 - 32 areas. The focal index, which shows the average number of diseased animals in one focus of disease, was maximum in 2012 - 163.2, which indicated the manifestation of the African swine fever in the form of epizootics and the minimum in 2014 - 7.7 reflecting the sporadic nature of the manifestation of the epizootic process.

Dynamics of changes in the number of adverse quarantine areas on the territory of Krasnodar region in the period of 2009-2019 reflects, on the whole, the pronounced tendency to decrease in the number of adverse areas, and especially in 2013 from 119 areas to 32 areas in 2019.

An increased risk of this group of diseases in Krasnodar region exists in March-AprilMay, June and August, because during these months of the year the highest number of cases of infection quarantines were recorded, including avian influenza and African swine fever. Quarantine infectious diseases were recorded among cattle in $55.9 \%$ of cases, pigs in $24.4 \%$, poultry - in $17.7 \%$; among other animal species - from $1.4 \%$ to $0.002 \%$ (Table $3)$. 
Table 3. The animal species structure of quarantine and infectious diseases in Krasnodar region in 2009-2019.

\begin{tabular}{|c|c|c|c|c|}
\hline \multirow{2}{*}{ Animal species } & \multicolumn{2}{|c|}{ Number of adverse areas } & \multicolumn{2}{c|}{ Number of cases } \\
\cline { 2 - 5 } & $\begin{array}{c}\text { absolute } \\
\text { values }\end{array}$ & $\mathbf{\%}$ & $\begin{array}{c}\text { absolute } \\
\text { values }\end{array}$ & $\boldsymbol{\%}$ \\
\hline Cattle & 406 & 53.8 & 22668 & 55.9 \\
\hline Small cattle & 30 & 4.0 & 555 & 1.4 \\
\hline Horses & 10 & 1.3 & 31 & 0.1 \\
\hline Swine & 94 & 12.5 & 9898 & 24.4 \\
\hline Poultry & 64 & 8.5 & 7169 & 17.7 \\
\hline Dogs & 69 & 9.1 & 122 & 0.3 \\
\hline Cats & 48 & 6.4 & 48 & 0.1 \\
\hline Wild animals & 33 & 4.4 & 34 & 0.1 \\
\hline Camels & 1 & 0.1 & 1 & 0.002 \\
\hline In total & 755 & 100 & 40526 & 100 \\
\hline
\end{tabular}

Depending on the number of identified adverse areas on quarantine infections, the territory of the region can be conditionally divided into three zones: a zone of high risk of desease occurrence, a zone of medium risk of desease occurrence and a zone of high risk of desease occurrence and further spread of quarantine infectious deseases.

The high risk zone for quarantine infections (more than 30 registered adverse areas) included five municipalities of the region (11.4\%): Otradnensky, Labinsky, Mostovsky, Belorechensky districts and Krasnodar.

In the Labinsky, Mostovsky and Otradnensky districts, from 85 to $83 \%$ of cases are associated with the incidence of livestock with brucellosis, in Krasnodar 53.6\% of cases with rabies and $23.2 \%$ of cases - with ornithosis, in Belorechensky district - $80 \%$ of cases with bovine leukosis virus infection.

The zone of medium risk of quarantine infections includes 10 municipalities (22.7\%), in which from 16 to 30 adverse areas are registered, the zone of minimal risk includes 29 districts of the region (65.9\%), in which from 1 to 15 adverse areas are registred.

\section{Conclusion}

Based on the research results, the following main conclusions can be drawn:

The epizootic situation on the territory of the Krasnodar region for quarantine and infections remains stable, despite the registration of 755 unfavorable points for quarantine infections over a 10-year period. Since 2013, the number of unfavorable points has decreased from 119 to 32 . An analogous trend is also observed in the reduction of the linear trend of focal incindence from 102.3 to 10.1 . The greatest focality during the study period was established for avian influenza - 112.9, ASF 105.3 and bovine leukemia -55.8.

Brucellosis accounts for the largest number of unfavorable points for animal quarantine diseases-30.7 \%, bovine leukemia-23.4\%, and African swine fever-20.4\%. Less than $1 \%$ for classic swine fever, nodular dermatitis, malignant oedema, swine pasteurellosis, equine heart disease, anthrax, and bovine emcar. Up to $0.1 \%$ - for Newcastle disease, foot-andmouth disease and bovine bluetongue, and braxy of sheep.

The forecast of the epizootic situation for brucellosis of large and small cattle, rabies of wild carnivores and small domestic animals, ASF, leptospirosis, bird flu is cautious.

\section{References}

1. The doctrine of food security of the Russian Federation, 
http://kremlin.ru/acts/bank/30563

2. S. Prutsakov, N. Kruzhnov, I. Bolotsky, V. Sementsov, Bulgarian Journal of Veterinary Medicine 18(2), 148-158 (2015)

3. Alexander Shevchenko, A. Litvinova, O. Chernykh, D. Mirrorev, Veterinary pathology 1(67), 11 (2019)

4. A, Panin, A. Kulikovskii, Veterinary science 2, 3-5 (2014)

5. Omazic, A. Högberg, A. Albihn, H. Bylund, C. Björkman, S. Boqvist, Acta Veterinaria Scandinavica 61(1), 53 (2019)

6. L. Tomassone, E. Berriatua, R. De Sousa, G. Duscher, A. Mihalca, C. Silaghi, H. Sprong, A. Zintl, Veterinary Parasitology 251, 17-26 (2018)

7. T. Chassovnikarova, A. Stojanova, Acta Zoologica Bulgarica 69(1), 3-8 (2017)

8. L. Christou, Clinical Microbiology \& Infection 17(3), 326-330 (2011)

9. L. Pimentel, E. Taylor, Surveillance for zoonotic diseases, 92-106 (2014)

10. P. Fernandes, W. White, Atlas of transboundary animal diseases (OIE, France, 2010)

11. G. Boseret, J. Mainil, Vet. Res. 44(36), 1-17 (2013)

12. M. Tarasov, A. Porshakov, S. Tolokonnikova, Disinfection case 4, 45-52 (2013)

13. J. Halliday, S. Cleaveland, H. Auty, K. Hampson, Z. Mtema, M. Bronsvoort, Surveillance and Monitoring of Zoonoses (BBSRC, Swindon, UK, 2014)

14. J. Taylor, Canadian Veterinary Journal 51, 1095-1102 (2010)

15. A. Dmitriev, S. Minaev, Veterinary pathology 1 (39), 41-46 (2012) 